\title{
Economics
}

\section{Test of relationship between Exchange Rate and Inflation in South Sudan: Granger-Causality Approach}

\author{
Emmanuel Pitia Zacharia Lado \\ Department of Economics, CSES, University of Juba, Juba, South Sudan
}

Email address:

epitia@yahoo.com,emmanuelpitia@ymail.com

\section{To cite this article:}

Emmanuel Pitia Zacharia Lado. Test of relationship between Exchange Rate and Inflation in South Sudan: Granger-Causality Approach. Economics.Vol. 4, No. 2, 2015, pp. 34-40.doi: 10.11648/j.eco.20150402.13

\begin{abstract}
Using Granger-causality approach, this study was intended to establish the relationship between exchange rate and inflation measured by CPI in South Sudan using time series monthly data for the period August 2011 to November 2014 . The study reveals that there exists a unidirectional causality from exchange rate to CPI without feedback. This means depreciation of South Sudanese currency is detrimental to the economy of South Sudan. Although CPI failed to cause changes in exchange rate, there is no way to conclude with greater confidence that the results are true. The effect of the pressure of an increase in price level on exchange rate could have been from the response of monetary authorities in bridging the gap between the price level and the purchasing power of people in the economy. In South Sudan, with no response from the monetary authorities to increase money supply, the effect of increase in prices on exchange rate has been suppressed and only manifests itself in terms of suffering encountered by the economic actors with consumers and mainly the low-income consumers hit hard.Given the results, there is a need for the authorities to manage the exchange rate and save the domestic currency from depreciation. In search of more information, the study recommends further research to be conducted with the aim of establishing the weaknesses and strengths of South Sudan Central Bank management in carrying out effective monetary policies in the country.
\end{abstract}

Keywords: Granger-Causality, Exchange Rate, CPI, South Sudan

\section{Introduction}

Exchange rate refers to the number of units of one nation's currency that equals one unit of another currency (Tucker, 2006: 427). In contrast, a consumer price index (CPI) is an index that measures changes in the average prices of consumer goods and services (Tucker, 2006: 245). Economic stability is one of the macroeconomic objectives every economy strives to achieve. Central in economic stability is the case of price stability. This has become a concern for every country to control inflation rate. Among drivers of inflation is the depreciation of the domestic currency relative to other currencies. The fall in the value of the domestic currency means that more units of the domestic currency are to be put together in exchange for a single unit of the foreign currency than it had been before the depreciation of the domestic currency. Therefore, in studying inflation, exchange rate cannot be neglected.

The fall in the value of a currency means that more units of the said currency are to be paid for a given assortment of commodities than previously. Such a situation causes individual economic actors to increase their demand for the domestic currency than before and in case of an increase in money stock, the domestic currency depreciates further and a subsequent increase in inflation rate follows.

\subsection{Background of South Sudan Economy}

South Sudan became an independent country in July 2011 seceding from Sudan in a referendum. In terms of resources, South Sudan is endowed with numerous resources. However, the only tapped mineral is the oil (petroleum). South Sudan, a newly established country appears to have started on a wrong footing due to its total dependence on oil export. The arable agriculture has been kept at a level of unsustainable subsistence.This makes the country dependent entirely on imported goods including the essential commodities. This situation increases the demand for US dollars to facilitate imports at the expense of the value of the local currency.

Additionally, there have been no improvements in education and health services and these have caused families 
to move their children (sons and daughters) to other countries in search ofquality education and the able people to look for better medical services abroad and this creates increased demand for US dollars. Equally, the case of the insecurity both during the day and night (e.g. night robbery and/or burglary) has caused people to move their families to the neighbouring countries the maintenance of which requires money in form of hard currency.This increases the demand for hard currency and consequently exerts a downward pressure on the value of South Sudanese Pound (SSP). As such, prices appear to have been moving upwards as a result the upward trends of the two variables (exchange rate and CPI)as shown in the graphs(Fig. $1.1 \&$ Fig. 1.2) below:

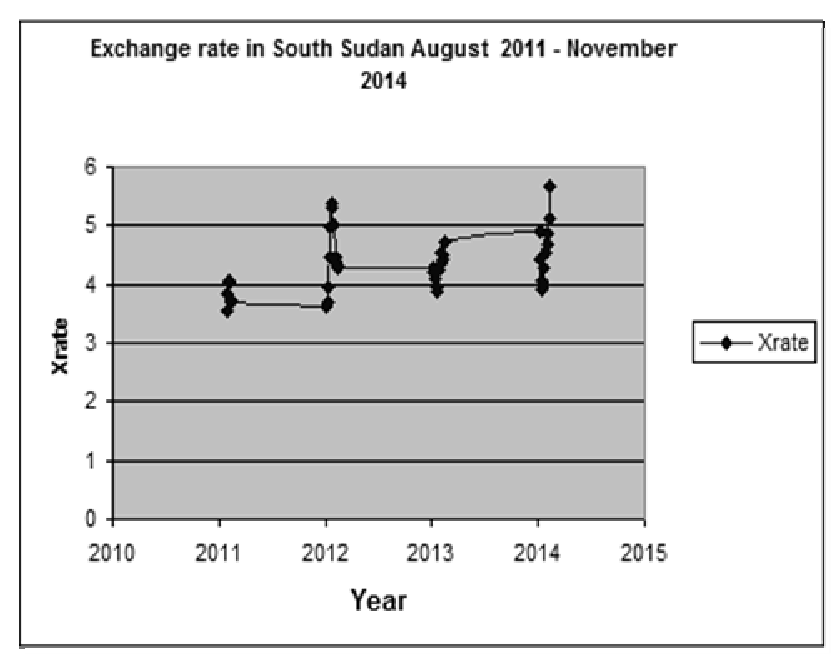

Fig. 1.1. Exchange rate in South Sudan August2o11 to November 2014.

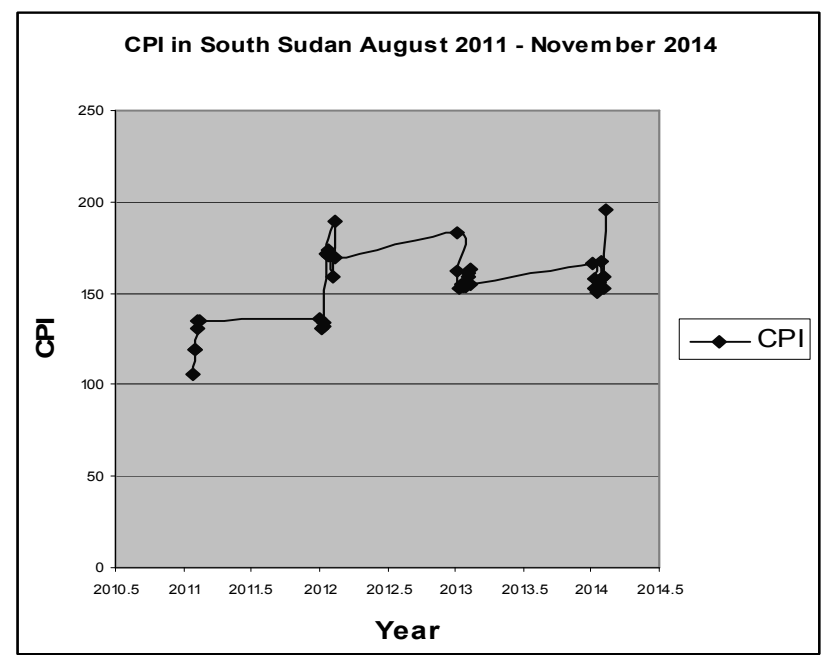

Fig. 1.2. CPI in South Sudan August2ol1 to November 2014

\subsection{Problem Statement}

The consequences of inflation on the economy in general and economic actors in particular are of great concern all over the world in which South Sudan is no exception. The endogeneity between exchange rate and inflation has become prevalent in economic literature. South Sudan being a newly established country lacks a study on the same. This study has sought to establish the relationship between exchange rate and inflation in the country using Granger-causality approach.

\subsection{Objectives of the Study}

In general, the study has been conducted to establish whether there exists any relationship between exchange rate and inflation in the country. In particular, the study was intended to:

(i) assess the relationship between exchange rate and inflation for the period covered in the study.

(ii) find out whether there exist any feedback effects between the two variables.

\section{Literature Review}

The literature review is broken down into two parts: The theoretical literature and the empirical literature.

\subsection{Theoretical Literature Review}

The literature on exchange rate and inflation has shown that the two variables affect each other positively (i.e. the changes in the two variables are in the same direction).

\subsubsection{Theories of Inflation}

The literature on inflation has been widely discussed by theorists. In the literature, three main types of inflation have been prevalent namely demand-pull inflation, cost-push inflation, and structural inflation (Dwivedi, 2009:546 -551, Vaish 2011, 499 - 503).

The demand-pull inflation occurs when the aggregate demand increases much more rapidly than the aggregate supply. The increase in aggregate demand may be caused by monetary factors (i.e. increase in money supply), and real factors (increase in demand for real output). That is, increase in money supply in excess of output is one of the most important factors causing demand-pull inflation. In addition, the real factors that cause inflation include taxes and government (public) expenditure (Dwivedi, 2009: 546, Vaish, and 2011:499).

The cost-push inflation is generally caused by monopolistic groups of society, like labour unions and firms in monopolistic and oligopolistic market setting. Strong labour unions often succeed in forcing money wages to go up causing increase in prices. This kind of rise in price level is called wage-push inflation. Also firms enjoying monopoly power have also been found using their monopoly power to raise prices which in turn causing a rise in the general price level. This kind of inflation is called profit-push inflation. Another kind of cost-push inflation is said to be caused by supply shocks (decrease in the aggregate supply). This is called supply shock inflation which in particular attributed to, for example, food prices shoot up due to crop failure, and increase in prices of some key industrial inputs. That is, this rise in prices may be caused by supply bottlenecks in the domestic economy or international events (generally wars) causing bottlenecks in the movement of traded goods and causing shortage of supply (Dwivedi, 2009: 548, Vaish, 
2011:503).

The structuralist theories of inflation were the work of structuralists and mainly attributed to the works of Myrdal, Streeten, and several Latin American economists who gave birth to structural inflation (Dwivedi, 2009: 551).According to the structuralist view, inflation in LDCs is an unavoidable result of their ambitious development programmes and is caused mainly by structural imbalances in such economies. The structural imbalances in LDCs' economies are (Dwivedi, 2009:551):

(i) food scarcity: the imbalance between the demand for and supply of food.

(ii) Input imbalance: shortage of capital and surplus labour, shortage of fuel and oil,

(iii) foreign exchange bottlenecks: imbalance between exports and imports and balance of payment deficits,

(iv) infrastructural bottlenecks: inadequate supply of electricity, transport and communication, and telecommunication and

(v) social and political constraints.

\subsubsection{Exchange Rate}

The effect of devaluation of domestic currency on inflation has been cited in the literature. Devaluation of domestic currency especially during periods of war is a cause of inflation (Livingstone, 1987). A low exchange rate of a given country's currency in relation to other currencies makes imports more expensive and exports cheaper and it can contribute to inflationary pressure at home country (Colander, 1998).

The effect of inflation on exchange rate can be explained through the theory of Purchasing Power Parity (Dornbusch and Fisher, 1994:621, Greenaway and Show, 1991:, Mishkin 2001: 157, Vaish 2011: 614). According to Purchasing Power Parity (PPP), the long-run neutrality of money illustrates the potential role of exchange rates in offsetting the effects of changes in the price level at home and abroad on the terms of trade. An important view of the determinants of exchange rate is the theory that exchange rates move primarily as a result of differences in price level behavior between any two countries in such a way as to maintain the terms of trade constant between the two countries. That is, the PPP theory argues that themovementsof exchange rates primarily reflect divergent rates of inflation between different countries. The theory practically states that given the terms of trade $\frac{e P_{f}}{P}$, when $P_{f}$ (foreign price level) and/or $P$ (domestic price level) changes, $e$ (exchange rate) changes in such a way as to maintain $\frac{e P_{f}}{P}$ constant. Greenaway and Show

explained expectations in terms of PPP concept. Accordingly, the PPP doctrine asserts that in a world of floating exchange rates, exchange rate $(E)$ movements serve to equalize the purchasing power of different currencies. Formally, if the current or spot rate of exchange is defined as the number of units of domestic currency $D_{c}$ per unit of foreign currency $F_{c}$ :
$E_{t}=\frac{D_{c}}{F_{c}}$ such that if

$\Delta E \succ 0$ denotes exchange rate depreciation

$\Delta E \prec 0$ denotes exchange rate appreciation

Then according to the purchasing Power Parity theorem,

$$
\dot{E}_{t}=\dot{P}_{d}-\dot{P}_{w}
$$

That is, changes in the spot rate are determined by the domestic rate of inflation $\left(\dot{P}_{d}\right)$ relative to the world rate of inflation $\left(\dot{P}_{w}\right)$, keeping all other things constant.

\subsection{Empirical Literature Review}

Madesha et al (2013) carried out an empirical test of the relationship between exchange rate and inflation in Zimbabwe. Using Granger-causality approach for the annual data 1980 to 2007 , the study established the existence of bidirectional causality. This means that the two variables were feeding each other.

Using Granger-causality approach, Khodeir (2012) conducted a study on 'inflation targeting in Egypt: the relationship between exchange rate and inflation', employing monthly data as of January 1990 to April 2008. The results of the study revealed that there was causality between the nominal exchange rate and inflation in Egypt with feedback effects. It means that the nominal exchange rate depreciation increases inflation and the new level of inflation results in a further exchange rate depreciation.

Mandizha (2014) conducted a study on the linkage between inflation and exchange rate depreciation in Zimbabwe employing time series monthly data (without specifying the range of data) using Granger causality approach. The results showed that in the first two months the causality ran from exchange rate depreciation to inflation (prices). This means from lag one to lag two, the Granger causality was unidirectional. However, in lag three (the third month), there was a feedback Granger-causality between inflation and exchange rate depreciation up to lag twelve. Similar results from two other studies in different countries by Maswana (2005), and Ahmed and Ali (1999) were established.

\section{Methodology of the Study}

\subsection{The Data}

In this study, time series monthly data were used covering the period August 2011 to November 2014. The data on consumer price index (CPI) as a measure of price level were collected from South Sudan National Bureau of Statistics (NBS). The data on exchange rate between SSP and USD were the parallel exchange rates and were collected from Bank of South Sudan (BOSS) which is the central bank of the country. Initially, the exchange rate data were collected in the form of daily exchange rates and were converted to 
monthly data by the author.

\subsection{The Model}

The model tested was the Granger causality model used to test the relationship between exchange rate and inflation in South Sudan.In this, the test involved estimating the following pair of regressions:

$$
\begin{aligned}
& \text { Xrate }_{t}=\sum_{i=1}^{n} \alpha_{i} C P I_{t-i}+\sum_{j=1}^{n} \beta_{j} \text { Xrate }_{t-j}+\varepsilon_{1 t} \\
& C P I_{t}=\sum_{i=1}^{n} \lambda C P I_{t-i}+\sum_{j=1}^{n} \delta_{j} \text { Xrate }_{t-j}+\varepsilon_{2 t}
\end{aligned}
$$

Where:

Xrate $=$ Parallel exchange rate between USDand SPP.

$C P I=$ Consumer Price Index which is a measure of inflation.

$t=$ Represents the time dimension in the time series.

\subsection{Method of Estimation}

The data were analyzed using Eviews version 8 employing the Granger-Causality test between Xrate and the CPI. In carrying out Granger-causality test on the two variables, one of the following four possible outcomes was expected (Cameron 2005: 385):

(i) Xrate causes CPI and CPI causes Xrate.

(ii) Xrate causes CPI and CPI does not cause Xrate.

(iii) Exrate does not cause CPI and CPI causes Exrate.

(iv) Xrate does not cause CPI and CPI does not cause Xrate.

For Granger-causality test to be conducted, the two variables (Xrate and CPI) have to be stationary (Gujarati, 2003:698, Gujarati et al, 2009: 688, Gujarati, 2011: 272). Initially the variables were subjected into the test of stationarity and were found to be non-stationary with each of them being I(1). Due to the presence of autocorrelations of the errors in testing each of the two variables, an ADF (Augmented Dickey-Fuller) was used instead of DF (DickeyFuller).The ADF model used for testing the stationarity of the two variables in levels was involving both the intercept and trend as below for each of the two variables due to the fact that the variables (Xrate and CPI) have both intercept and trend as they appear in figures $1.1 \& 1.2$ above. The ADF test was therefore used to test the below equations:

$$
\begin{gathered}
\text { Xrate }_{t}=\beta_{1}+\beta_{2} t+\beta_{3} \text { Xrate }_{t-1}+\sum_{i=1}^{m} \alpha_{i} \text { Xrate }_{t-i}+\varepsilon_{1 t} \\
C P I_{t}=\delta_{1}+\delta_{2} t+\delta_{3} C P I_{t-1}+\sum_{j=1}^{n} \varphi_{i} C P I_{t-i}+\varepsilon_{2 t}
\end{gathered}
$$

The decision whether to include a constant, a constant and a trend or neither of these, into the test equation, was taken on the basis of the following: the series for each of the two variables was graphed and then observed, if the series did not exhibit any trend and has a nonzero mean, a constant was included in the test regression, if the series exhibited a trend and a constant (as they appear in figures $1.1 \& 1.2$ ), then a constant and a trend were included. While if the series failed to show either a constant, or both constant and trend, then neither would be included into the test equation (which was not the case with the data in levels for this study).That is, in levels, the two variables exhibited both a constant and a trend (as in figures $1.1 \& 1.2$ above) andtherefore the two (a constant and a trend) were included into the tests. However, after having identified that the variables were I(1) i.e. nonstationary in levels, the two variables were differenced once. When the variables were in their first differences, each of them was identified to have neither an intercept nor intercept and trend.

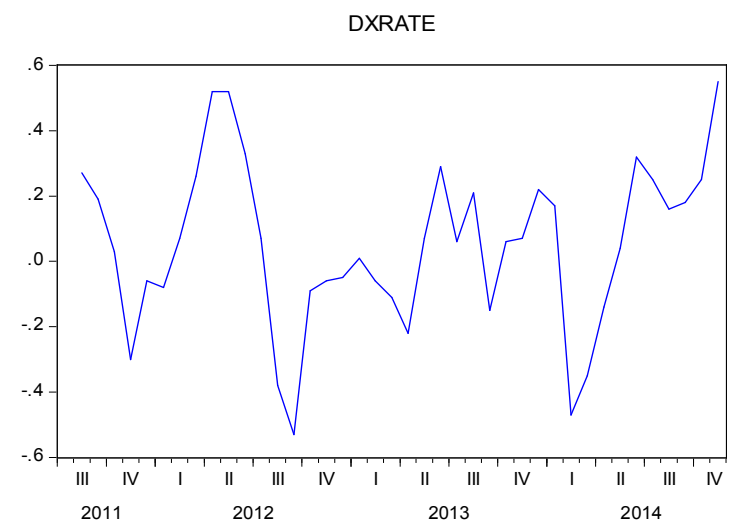

Fig. 3.1. The graph of exchange rate in firstdifference.

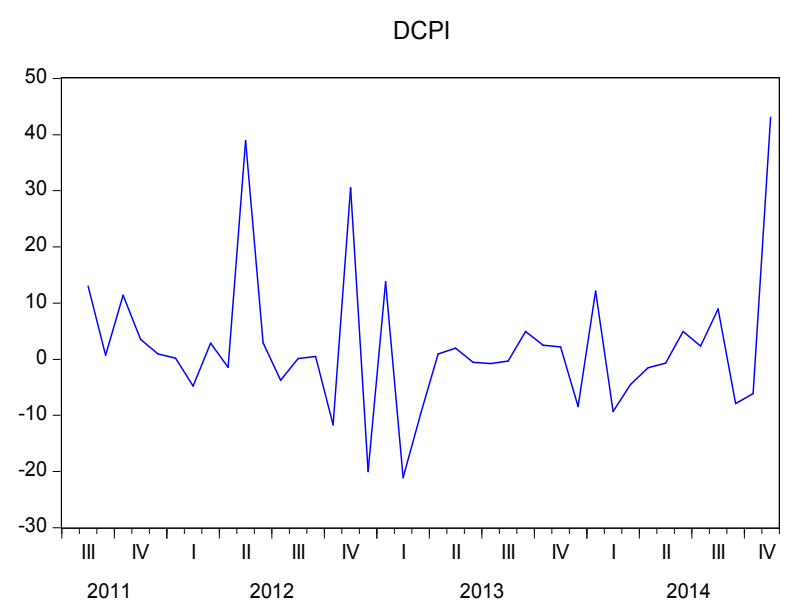

Fig. 3.2. The graph of CPI in first difference.

As can be seen in the above graphs (figures $3.1 \& 3.2$ ) of the two variablesin theirfirst differences, it is evident that each of the variables has neither an intercept nor both intercept and trend. At the same time, each of the two variables in first difference was having autocorrelations up to lag two and as such the test of each of the variables in first difference had to involve three lags by employing the ADF test of stationarity. The results revealed that the two variables were stationary in their first differences. The ADF test for each of the two variables in first difference was carried out as below: 


$$
\begin{gathered}
\Delta \text { Xrate }_{t}=\beta_{1}+\sum_{i=1}^{3} \alpha_{i} \Delta \text { Xrate }_{t-i} \\
\Delta C P I_{t}=\delta_{1}+\sum_{j=1}^{3} \varphi_{j} \Delta C P I_{t-j}
\end{gathered}
$$

Table 4.1. Results of Granger-causality test between exchange rate and CPI.

\begin{tabular}{llll}
\hline Direction of causality & Number of lags & F-Statistic & P-value \\
\hline$\Delta$ Xrate does not granger cause $\Delta C P I$ & 2 & 5.03862 & 0.0123 \\
$\Delta C P I$ does not granger cause $\Delta$ Xrate & 2 & 0.09532 & 0.9093 \\
$\Delta$ Xrate does not granger cause $\Delta C P I$ & 4 & 2.53617 & 0.0632 \\
$\Delta C P I$ does not granger cause $\Delta$ Xrate & 4 & 0.90081 & 0.4773 \\
$\Delta$ Xrate does not granger cause $\Delta C P I$ & 6 & 3.51385 & 0.0145 \\
$\Delta C P I$ does not granger cause $\Delta$ Xrate & 6 & 0.45527 & 0.8331 \\
$\Delta X$ rate does not granger cause $\Delta C P I$ & 8 & 3.15069 & 0.0265 \\
$\Delta C P I$ does not granger cause $\Delta X$ rate & 8 & 0.30008 & 0.9546 \\
$\Delta X$ rate does not granger cause $\Delta C P I$ & 9 & 2.54800 & 0.0667 \\
$\Delta C P I$ does not granger cause $\Delta$ Xrate & 9 & 0.36393 & 0.9316 \\
\hline
\end{tabular}

As can be seen inTable4.1 above, the results of the Granger-causality show that the causality is unidirectional only. The results concur with the findings of studies conducted by Maswana (2005), Ahmed and Ali (1999), and Mandizha (2014) for the first two months. However, from lag three onwards, this study has not shown any feedback causality between the two variables as opposed to the other studies cited above. This means that it is the exchange rate that causes CPI in the country without any feedback. This has been true for all the lags from lag one to lag nine. It is only in lag ten that the two variables became independent of each other. Throughout the nine-month period, CPI does not Granger-cause exchange rate. To save a space, the results presented are only of the even number lags with exception of lag nine that has been included.The fact that exchange rate Granger causes changes in inflation rate, does not necessarily mean that, a change in exchange rate will cause (unlike regression results) a subsequent change in inflation rate. It does mean that the past values of the exchange rate appear to contain information that is useful for forecasting changes in the inflation rate, beyond that contained in past values of the inflation rate (Gary 2009:193, Stock \& Watson, 2007: 547). Possibly, the CPI could not influence the exchange rate in South Sudan because the monetary authorities do not respond to a fall in the purchasing power of the public caused by the increase in the general price level. In this case import prices are acting as a transmission mechanism from exchange rate to domestic prices (Hafer, 1989). The import prices in South Sudan are affecting domestic general price levelgreatly as generally the country depends on foreign goods for consumption to a greater extent. Additionally, the country's general price level is affected through imported inputs especially building materials (e.g. cement, iron, and similar others). A rise in the prices of these materials makes the cost of building/construction to rise and as a result a rise in rental prices. While in other countries, the effect of import prices on domestic price level caused by depreciation of the country's

\section{Results and Discussion}

The results of the Granger-causality between exchange rate and inflation are presented in Table 4.1. Below: domestic currency can be reduced through substitution effect;in South Sudan this is not possible as the country does not produce enough consumer goods for its citizens. In economic theory, an increase in price level can be determined by price elasticities of demand and supply. In a situation where the demand for a commodity is price elastic, an increase in price is likely to cause a big fall in the demand for a commodity and this is likely to cause the seller to initiate a downward change of the price of the commodity. In South Sudan, the demand for the imported commodities is price inelastic due to lack of alternatives at home. At the time the paper was being worked out, there has been a decrease in housingrents. This has been attributed to the ongoing war in the country which erupted in mid December 2013 that has made both the nationals and foreigners alike to move away from South Sudan. However, this seems to be a temporary shock to housing rental prices

\section{Conclusions}

The study was carried out with an objective to identify the relationship between exchange rate and consumer price index (as a measure of inflation) in South Sudan using Grangercausality approach employing monthly data for the period August 2011 to November 2014. The results reveal that there has been a unidirectional link running from exchange rate to consumer price index in the country. This means that exchange rate has the information about changes in CPI in the country but not the other way round. Although exchange rate is seen to be the cause of CPI changes in the country, there is need to understand that exchange rate is a symptom of deep economic and/or financial crises caused by crises in the governance and/or insecurity situation in the country. Poor governance manifests itself in different forms including lack of production in agricultural sector (both arable and animal). South Sudan is a country having plenty of animals and fertile arable land. However, arable agricultural initiative 
has never been undertaken by the government since South Sudan independence in 2011. At the same time, South Sudan is now depending on cattle (bulls), goats and sheep imported from Uganda due to the fact that cattle in South Sudan are reared traditionally for prestige. This has made the country to be over dependent on the neighboring countries: Uganda, Kenya, and Sudan and thus making the earlier pride and/or joy of independence to wane. The insecurity in the country has caused families of the financially able people to move abroad that are to be supported by their heads of households/breadwinners in South Sudan and hence drains the country of its foreign reserves (mainly US dollars). The government has failed to provide for standard educational and health services in the country. In terms of education, the able families have moved their sons and daughters to foreign countries for education. This has become an expensive invisible import to South Sudan. Another invisible import to South Sudan that deprives the country of its foreign reserves is the medical treatment abroad such as but not limited to India, Sudan, Kenya, and Uganda. All these mean a high demand for US dollars and thereby a scarcity of this currency and thus exerts more pressure on the value of the domestic currency - the South Sudanese pound - and hence its devaluation.

The mid-December 2013 crises in South Sudan equally affected the value of the local currency as the foreign direct investors have been leaving the country for their own and business safety. During the relocation of the foreign investors outside of South Sudan, there was a great demand for US dollars and less demand for the SSP and that led to the weakening of the local currency and hence depreciation.

Putting all the above together means South Sudan is yet to experience more difficult times ahead if no immediate action is taken. The fact that CPI does not Granger-cause exchange rate cannot be confidently concluded that this is true but may be it affects exchange rate indirectly. Economically, a rise in price level caused by depreciation, means that the monetary authorities would end up increasing money supply to fill the gap in purchasing power caused by the increase in the general price level. This would cause a further depreciation of the domestic currency. That is, expectations about changes in money supply play an important role in determining exchange rate and as such there is an exchange rate overshooting when the money supply increases (Mishkin, 2001: 172-173). However, in South Sudan, the monetary authorities do not care about the suffering of the citizens caused by the increasing price level and as such do not increase the money supply or wages in the country to fill up the gap created by increasing price level. At the same time, the labour union in the country is weak and/or subservient to the government and as such lacks the power to push the government to increase wages and as such no increase in money supply (stock of money in circulation).

As the country is politically unstable given the war and insecurity in all areas including those that are outside the war zones, improvement in agricultural sector cannot be expected too soon. Again, with war in the country coupled with lack of clear economic policies in place, it would be difficult if not impossible for any economic stability to come by in the near future.For a country not to suffer from rising price levels there has to be a clear economic policy or policies on how the country's currency can be saved from further depreciation. Although the government is using the fixed exchange rate system, in practice the economy is highly affected by the black market (parallel) exchange rates and the official fixed exchange rate is nowhere to influence the working of the economy and hence the value of the local currency continuously depreciates regardless. This means, nominally South Sudan has the fixed exchange rate system but in practice no economic policies have ever been employed to effectively guard against the devaluation of the national currency. The best exchange rate system for South Sudan would have been the managed exchange rate system.

Although the study has managed to achieve its intended objectives, it has not gone far enough to understand why the Government of South Sudan is not so much concerned about the falling value of the local currency. The study, therefore, recommends another research to be carried out that has to take into consideration the weaknesses and strengths of the central bank management in planning and managing monetary policies in the country. Questions that a new study could seek answers for include: Is it a weakness of the government making the economy to suffer from continuous devaluation of the SSP or what was rumoured about the government of South Sudan intention to devalue the South Sudanese currency to have exchange rate parity with Sudanese currency is now taking place in a coolmood (so as to avoid the frustrations of the economic actors)?

\section{References}

[1] Ahamed, E \& A.S. Ali .1999. Exchange rate and Inflation dynamics, The Pakistan Development Review, Vol. 38, No. 3, PP. $235-251$.

[2] Cameron, Samuel .2005. Econometrics, McGraw-Hill Education, UK.

[3] Colander, D.C .1998. Macroeconomics, 3rd ed., the McGrawHill Companies, Inc., USA.

[4] Donrnbusch, Rudiger and Stanley Fischer .1994. Macroeconomics, $6^{\text {th }}$ ed., McGraw-Hill INC., USA

[5] Dwivedi, D N .2009. Managerial Economics, $7^{\text {th }}$ ed., Vikas Publishing House, Delhi, India.

[6] Greenaway, D. and G.K. Shaw .1991.macroeconomics: Theory and Policy in UK, $2^{\text {nd }}$ ed., Basil Blackwell Ltd, UK.

[7] Gujarati, Damodar N.2003. Basic Econometrics, $4^{\text {th }}$ ed., McGraw-Hill, Singapore.

[8] ... 2011. Econometrics BY Example, Palgrave MacMillan, UK.

[9] Hafer, Rik (1989) Does Dollar Depreciation cause Inflation?, Federal Reserve Bank of St. Louis Review, Vo.71.No. 4, PP 16-28. 
[10] Ito, T \& K. Sato .2007. Exchange rate pass-through and domestic inflation: Acomparison between East Asia and Latin American countries, REITI Discussion Paper Series No. 07.

[11] Khodier, Aliaa Nabil .2012. Towards Inflation Targeting in Egypt: The Relationship between Exchange Rate and Inflation, SAJEMS NS, No. 3

[12] Koop, Gary .2009. Analysis of Economic Data, $3^{\text {rd }}$ ed., A John Wiley \& Sons, Ltd, England.

[13] Livingstone, I. Diejomaoh et al .1987. Economics for West Africa, $2^{\text {nd }}$ ed., Heinemann Educational Books, Britain.

[14] Madesha, Wellington et al .2013. Empirical Test of the Relationship Between Exchange Rate and Inflation in Zimbabwe, Journal of Economics and Sustainable Development, Vol. 4, No.1.
[15] Mandizha, Blessing .2014. Inflationand Exchange Rate Depreciation: AGranger causality Test at the Naissance of Zimbabwe Infamous Hyperinflation (2001-2005), Economics and Finance Review, Vo.3. No. 9, PP. 22-42.

[16] Maswana, J.C. 2005. Money, exchange rate and price links during hyperinflation episodes in developing economies, Graduate School of Economics, Kyoto University Japan.

[17] Mishkin, Frederic S. 2001. The Economics of Money, Banking, and Financial markets, $6^{\text {th }}$ ed., Library of Congress Cataloguing-in-Publication data, USA.

[18] Stock, James H. \& Mark W. Watson .2007. Introduction to Econometrics, 2nd ed., Person Education Inc., USA.

[19] Tucker, Irvin B.2006. Survey of Economics, $5^{\text {th }}$ ed., Thomson South-Western, USA.

[20] Vaish, M.C. 2011. Macroeconomic Theory, $14^{\text {th }}$ ed., Vikas Publishing House PVT LTD, India. 